PaweŁ CZAPlińsKi

Akademia Pomorska, Słupsk, Polska

\title{
Formowanie się nowej struktury przestrzennej przemysłu przetwórstwa rybnego w Polsce
}

\author{
Creating a New Spatial Structure \\ of Fish Processing Industry in Poland
}

\begin{abstract}
Streszczenie: $\mathrm{W}$ artykule ${ }^{1}$ podjęto rozważania dotyczące określenia wagi czynników i korzyści z lokalizacji dla przemysłu przetwórstwa rybnego w Polsce oraz ich wpływu na zmiany struktury przestrzennej. Ponadto dokonano charakterystyki zmian w rozmieszczeniu przedsiębiorstw przetwórczych w Polsce, ze szczególnym uwzględnieniem ich koncentracji w świetle teorii klastra. Obecnie, najistotniejszymi czynnikami lokalizacji w przetwórstwie rybnym w Polsce są czynniki związane z zasobami pracy, tj. czynnik kosztowy, kompetencyjny, kulturowy. Jednak znaczenie poszczególnych czynników jest bardzo zróżnicowane pod względem wielkości przedsiębiorstw i ich położenia. Obserwowany proces dekoncentracji badanej grupy przemysłowej dotyczy głównie spadku wielkości potencjału przetwórstwa rybnego w województwach nadmorskich (pomorskie i zachodniopomorskie). Nowe lokalizacje przedsiębiorstw, a także zmiany organizacyjno-własnościowe (m.in. relokacja) w obrębie jednostek już istniejących spowodowały powstanie „nowych” lub przeformułowanie „starych” koncentracji przedsiębiorstw przetwórczych. Nowa formuła działania miałaby się opierać na teorii klastra. Jednak proces ich tworzenia w skali kraju jest raczej na etapie inkubacji.
\end{abstract}

Abstract: The article is an attempt to determine the weight of factors and advantages of location for
fish processing industry in Poland and their influence on the changes in the spatial structure. What is
more, the changes in distribution of food processing companies in Poland were characterized taking
into consideration their concentration in view of the theory of cluster. At present the most crucial
location factors in fish processing in Poland are the ones connected with labour resources which are
cost, competence and culture factors. Market factors of quality character (for example market wealth)
constitute the second group in terms of importance. The observed process of deconcentration study
industrial group concerns mostly the decrease in the amount of fish processing potential in coastal
voivodeships (Pomeranian and West Pomeranian Voivodeships). New locations of companies and also
organizational and ownership changes within already existing units (relocation, among others) have
caused to come into existence "new" or reformate "old" concentrations of food processing companies.

1 Praca naukowa finansowana ze środków budżetowych na naukę w latach 2010-2013 jako projekt badawczy NN 306072739 „Przestrzenny wymiar transformacji przemysłu przetwórstwa rybnego w Polsce”. 
A new formula of activity might be based on the theory of cluster. However, the process of creating them on the national scale is rather at the stage of incubation.

Słowa kluczowe: przemysł przetwórstwa rybnego, lokalizacja, rozmieszczenie, struktura przestrzenna, klaster

Key words: fish processing industry, location, distribution, spatial structure, cluster

\section{WPROWADZENIE}

Teoria lokalizacji, która w ujęciu klasycznym sprowadza się do położenia obiektu/ obiektów w przestrzeni względem innych elementów tej przestrzeni, rozwija się obecnie w trzech kierunkach (Mc Cann, Shepard 2003; Dziemianowicz 2008; Stryjakiewicz 2010). Pierwszy z nich dotyczy prawidłowości powstawania i rozmieszczania skupisk działalności gospodarczej. Drugi odnosi się do potrzeby redefiniowania przestrzennych kosztów transakcyjnych w kontekście nowych trendów społeczno-ekonomicznych. Trzeci polega na wprowadzeniu do teorii czynnika środowiskowego, rozumianego jako specyficzne warunki lokalne. W świetle problemu nakreślonego tematem artykułu, który nawiązuje głównie do pierwszego z wymienionych kierunków, celem podjętych badań było określenie wagi wytypowanych czynników lokalizacji dla przemysłu przetwórstwa rybnego oraz opisanie ich wpływu na zmiany struktury przestrzennej. Definicję czynników lokalizacji przyjęto za Godlewską (2001), Wielońskim (2005) i Kucińskim (2009), którzy za czynniki lokalizacji uznali „specyficzne cechy poszczególnych miejsc, mające bezpośredni wpływ na kształtowanie się nakładów inwestycyjnych w trakcie budowy obiektów firmy, a także rentowność netto działalności gospodarczej realizowanej w tych miejscach". Proces badawczy przeprowadzono w oparciu o metodę terenową z wykorzystaniem kwestionariusza. Na wstępnym etapie badań zastosowano metodę delficką², dzięki której wyłoniono 30 kluczowych dla funkcjonowania przemysłu przetwórstwa rybnego czynników lokalizacji. Wytypowane czynniki podzielono na 6 grup po 5 czynników. Należy dodać, że umiejscowienie grup czynników oraz poszczególnych czynników na liście, a także oznaczenie (znak) jest przypadkowe i nie odnosi się do ich rangi (tab. 1). Właściwe badanie polegało na ocenie przez przedsiębiorców przemysłu przetwórstwa rybnego czynników lokalizacji z punktu widzenia określonego miejsca funkcjonowania konkretnego zakładu przetwórczego. Każdy z czynników został oceniony w skali od 1 do 5 punktów, przy czym „1” oznaczało minimalną możliwą ocenę, ,5” ocenę maksymalną. W skali ocen nie wykorzystano „0”, ponieważ po konsultacjach z ekspertami wyodrębniono czynniki, których minimalna istotność wynosi 1 punkt. Podmiotem badań były przedsiębiorstwa przetwórcze uprawnione do sprzedaży swoich wyrobów na rynek krajowy oraz rynek UE. W wyniku przeprowadzonych badań terenowych otrzymano 59 ankiet, co stanowi 20,6\% ogółu przedsiębiorstw wytypowanych do badań. Końcowym etapem badań była próba odniesienia wagi wytypowanych czynników lokalizacji do zmian w strukturze przestrzennej przemysłu przetwórstwa rybnego w Polsce.

2 Głównym ekspertem był Prezes Polskiego Stowarzyszenia Przetwórców Ryb z siedzibą w Koszalinie (www.pspr.pl). 


\section{CZYNNIKI LOKALIZACJI PRZEDSIĘBIORSTW PRZEMYSŁU PRZETWÓRSTWA RYBNEGO}

Z otrzymanych odpowiedzi wynika, że przedsiębiorstwa znacząco różnią się w ocenie istotności zaproponowanych czynników lokalizacji. Dotyczy to zarówno grup jak i poszczególnych czynników (ryc. 1).

Tab. 1. Czynniki lokalizacji uwzględnione w badaniach przedsiębiorstw przemysłu przetwórstwa rybnego w Polsce

\begin{tabular}{|c|c|c|c|c|}
\hline Grupa & Czynnik & Znak & $\begin{array}{c}\text { Suma } \\
\text { ocen }\end{array}$ & $\begin{array}{c}\text { Waga } \\
\text { czynnika }\end{array}$ \\
\hline \multirow[t]{5}{*}{ Rynek } & Bliskość rynku & A1 & 219 & $74,2 \%$ \\
\hline & Możliwość wejścia na rynek & $\mathrm{A} 2$ & 183 & $62,0 \%$ \\
\hline & Chłonność rynku & A3 & 172 & $58,3 \%$ \\
\hline & Zamożność rynku & A4 & 214 & $72,5 \%$ \\
\hline & Istnienie na rynku firm konkurencyjnych & A5 & 165 & $55,9 \%$ \\
\hline \multirow[t]{5}{*}{ Koszty } & Koszty bieżące & B1 & 180 & $61,0 \%$ \\
\hline & Koszty pracy & $\mathrm{B} 2$ & 238 & $80,7 \%$ \\
\hline & Koszty inwestycyjne & B3 & 164 & $55,6 \%$ \\
\hline & Koszty podatkowe & B4 & 195 & $66,1 \%$ \\
\hline & Koszty transportu & B5 & 180 & $61,0 \%$ \\
\hline \multirow[t]{5}{*}{ Dostępność } & Dostępność do kooperantów & $\mathrm{C} 1$ & 217 & $73,6 \%$ \\
\hline & Dostępność komunikacyjna & $\mathrm{C} 2$ & 200 & $67,8 \%$ \\
\hline & Dostępność do wykwalifikowanych kadr & $\mathrm{C} 3$ & 235 & $79,7 \%$ \\
\hline & Dostępność do firm obsługujących & $\mathrm{C} 4$ & 180 & $61,0 \%$ \\
\hline & Dostępność do źródeł surowca & $\mathrm{C} 5$ & 196 & $66,4 \%$ \\
\hline \multirow[t]{5}{*}{ Stabilność } & Stabilność prawna & D1 & 202 & $68,5 \%$ \\
\hline & Stabilność polityczna & $\mathrm{D} 2$ & 174 & $60,0 \%$ \\
\hline & Stabilność makroekonomiczna & D3 & 198 & $67,1 \%$ \\
\hline & Stabilność podatkowa & D4 & 191 & $64,7 \%$ \\
\hline & Stabilność administracyjna & D5 & 127 & $43,1 \%$ \\
\hline \multirow[t]{5}{*}{ Ludzie } & Postawy pracowników & E1 & 221 & $75,0 \%$ \\
\hline & Jakość lokalnego otoczenia biznesu & E2 & 201 & $68,1 \%$ \\
\hline & Mentalność społeczności lokalnej & E3 & 170 & $57,6 \%$ \\
\hline & Współpraca z władzami samorządowymi & E4 & 194 & $65,8 \%$ \\
\hline & Demografia społeczności lokalnej & E5 & 111 & $37,6 \%$ \\
\hline \multirow[t]{5}{*}{ Miejsce } & Położenie fizyczno-geograficzne & F1 & 107 & $36,3 \%$ \\
\hline & Wizerunek miejsca lokalizacji & $\mathrm{F} 2$ & 195 & $66,1 \%$ \\
\hline & Poziom rozwoju lokalnego & F3 & 174 & $59,0 \%$ \\
\hline & Obieg informacji lokalnej & F4 & 171 & $58,0 \%$ \\
\hline & Stan środowiska przyrodniczego & F5 & 163 & $55,3 \%$ \\
\hline
\end{tabular}

Waga czynnika - \% sumy maksymalnych ocen

Źródło: opracowanie własne 
Najistotniejszymi czynnikami lokalizacji dla całej badanej grupy były koszty pracy i dostępność do wykwalifikowanych kadr. Przyczyn tak wysokich wartości dla wymienionych czynników należy upatrywać w bardzo tradycyjnym i pracochłonnym sposobie przetwarzania surowca rybnego, jego wysokiej wrażliwości na obróbkę mechaniczną oraz w indywidualnych, często wynikających z lokalnej tradycji umiejętnościach, które w świetle braku standardu surowca, a jeszcze bardziej szkolnictwa zawodowego nabierają specjalnego znaczenia i ceny. Ponadto wysoka pozycja czynnika koszty pracy może oznaczać poszukiwanie nowych miejsc lokalizacji przedsiębiorstw, które nie muszą być związane ze strefą nadmorską.

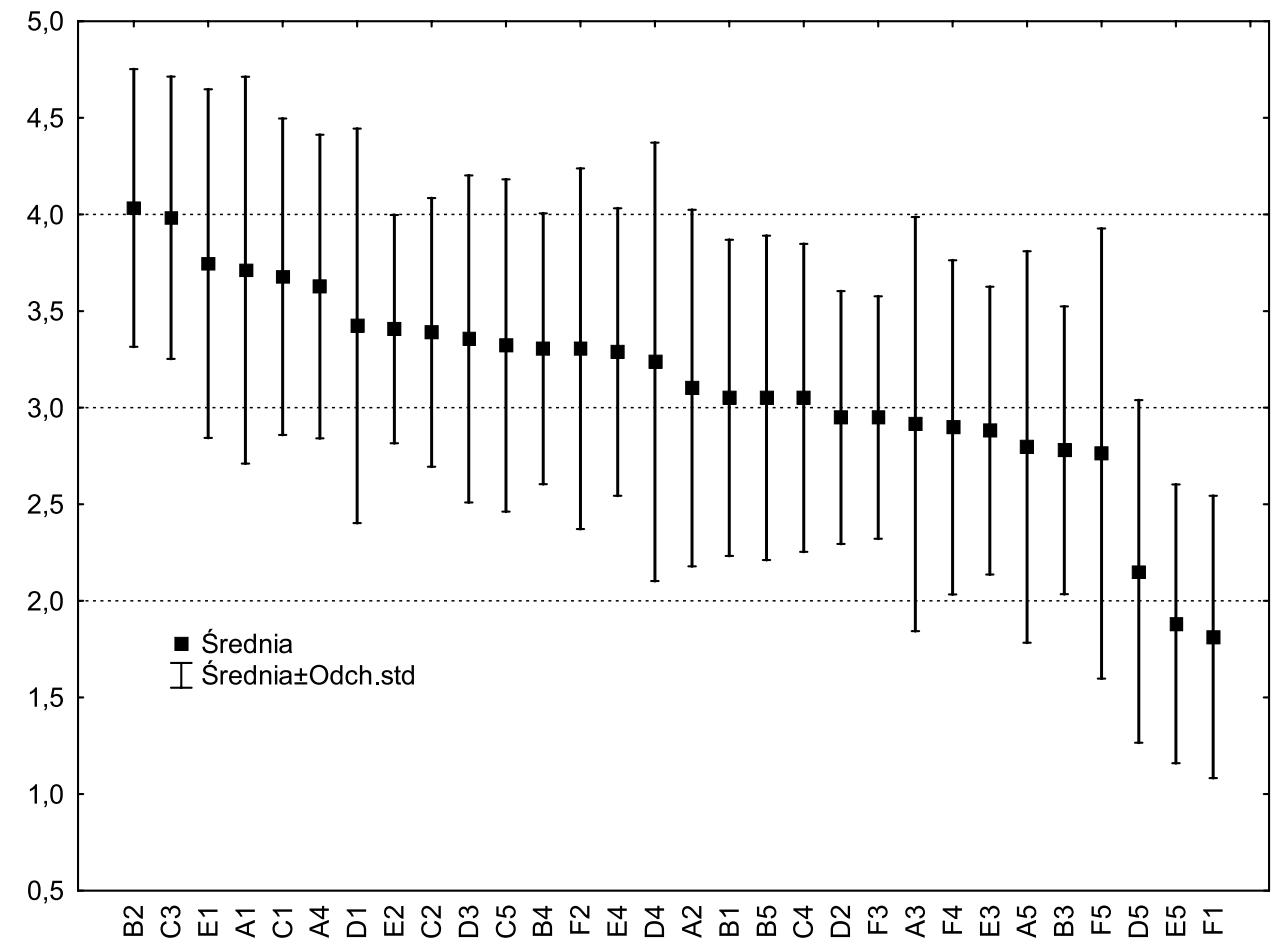

Ryc. 1. Średnia wartość czynników lokalizacji na podstawie badanych przedsiębiorstw Źródło: opracowanie własne

Drugą pod względem uzyskanych wyników grupę czynników lokalizacji stanowią czynniki rynkowe. Mogą one wskazywać na nowe motywy podejmowania działalności przetwórczej w nowych miejscach lokalizacji (np. na zapleczu dużych aglomeracji). Ważny jest również czynnik dostępność do kooperantów, informujący o konieczności współpracy w ramach więzi aktywnych i pasywnych, a także o już trwającym procesie konsolidacji rynku rybnego. Wreszcie czynnik postawy pracowników, który należy wiązać z lokalną kulturą wytwarzania oraz lokalną przedsiębiorczością.

Pomijając ograniczenia i niedoskonałości metodologiczne badań należy stwierdzić, że otrzymane wyniki skłaniają do wniosku, że nie istnieje jeden charakterystyczny zestaw 
czynników lokalizacji reprezentujący wszystkie przedsiębiorstwa przemysłu przetwórstwa rybnego w Polsce. Rodzi się zatem pytanie, czy istnieje zależność wyboru czynników lokalizacji od np. wielkości przedsiębiorstwa lub/i jego położenia?

$\mathrm{Na}$ podstawie przeprowadzonego grupowania ze względu na wagę czynników lokalizacji wyróżniono cztery grupy przedsiębiorstw najbardziej do siebie podobnych, których podobieństwo w dużej mierze wynika z ich wielkości. W szczególności dotyczy to grupy przedsiębiorstw dużych i mikroprzedsiębiorstw (ryc. 2).

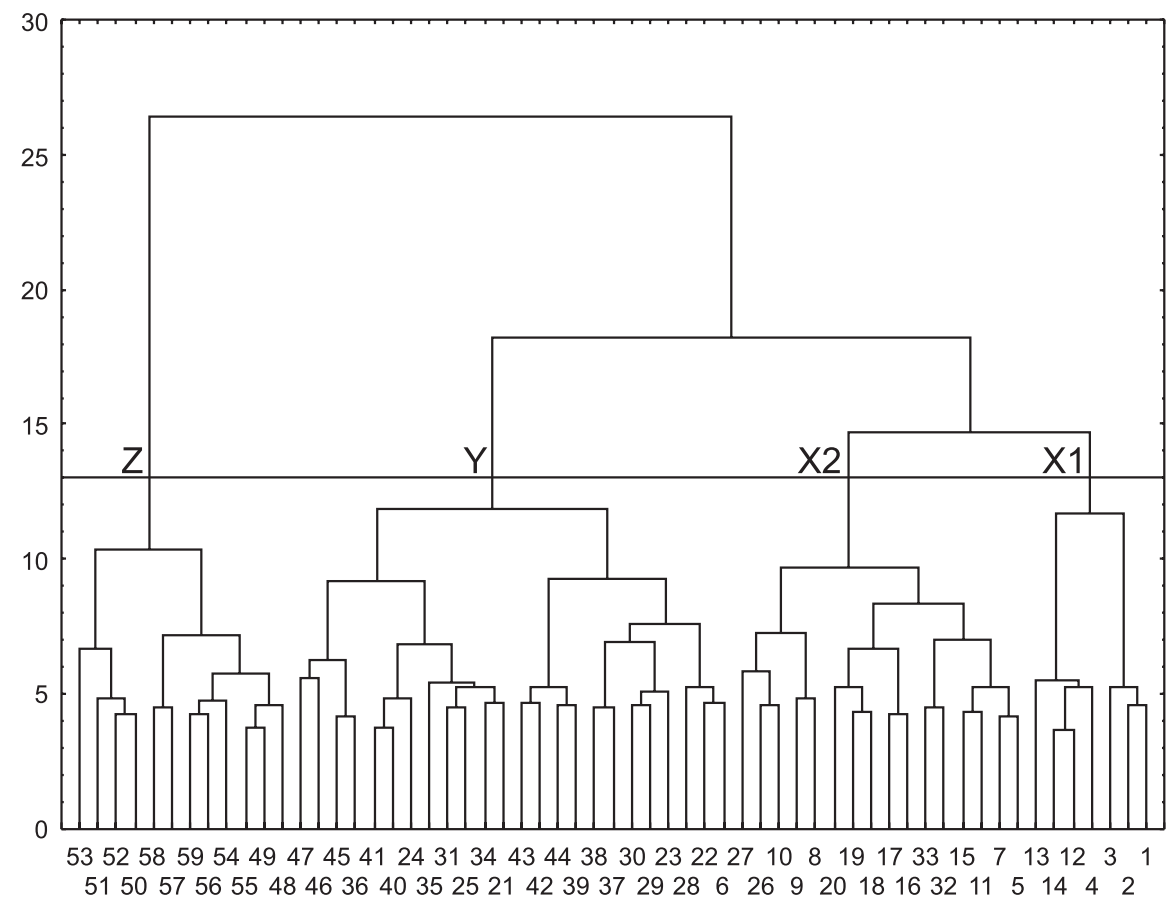
Numeracja przedsiębiorstw: 1-3 przedsiębiorstwa duże 4-18 przedsiębiorstwa średnie 19-43 przedsiębiorstwa małe 44-59 przedsiębiorstwa mikro

(3)

Ryc. 2. Grupowanie przedsiębiorstw przemysłu przetwórstwa rybnego ze względu na wagę czynników lokalizacji metodą Warda

Źródło: opracowanie własne

Wyodrębnione grupy wykazują wiele różnic w postrzeganiu i ocenie przedstawionych czynników lokalizacji, poza różnicami w rozpiętości i rozproszeniu ocen. Zasadniczy wydaje się być stosunek do bazy surowcowej, powiązań kooperacyjnych i znaczenia tzw. czynników miękkich, które w przypadku dużych przedsiębiorstw w zasadzie nie wystąpiły. Istnieją także wspomniane wcześniej analogie. Najistotniejszą z nich jest znacząca rola zasobów pracy, co należy odczytywać jako pewne novum w przetwórstwie, bowiem wcześniej podkreślano wagę bliskości bazy surowcowej i powiązań z rybołówstwem (Czapliński 1999). 
Badania komplementarne wykorzystujące analizę elementarnego połączenia Mc Quitty’ego potwierdzają zależność pomiędzy umiejscowieniem i wielkością przedsiębiorstw, a wskazywanym zestawem korzyści z lokalizacji (ryc. 3).

Istnieją jednak grupy, które należy uznać za mieszane, czyli takie, które w swej strukturze zawierają zarówno przedsiębiorstwa położone w województwach nadmorskich jak i poza nimi. Występowanie grup mieszanych wynika z ponadregionalnych powiązań:

- położenia przedsiębiorstw w bezpośrednim sąsiedztwie regionów nadmorskich (np. północna część województwa lubuskiego, wielkopolskiego, kujawsko-pomorskiego oraz północno-zachodnia część województwa warmińsko-mazurskiego) - przykład grupy 12,

- funkcjonowania jednostek produkcyjnych o różnej lokalizacji w ramach grup kapitałowych (np. GK Gral S.A.) - grupa 4 i 9 ,

- lokalnych powiązań organizacyjno-produkcyjnych wśród małych i mikro przedsiębiorstw - grupa 17,

- chęci naśladownictwa przedsiębiorstw, które odniosły sukces - grupa 14,

- powiązań bilateralnych o charakterze przetwórczo-handlowym - grupa 16.

G 1
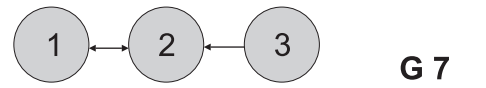

(25) $\rightarrow 31$
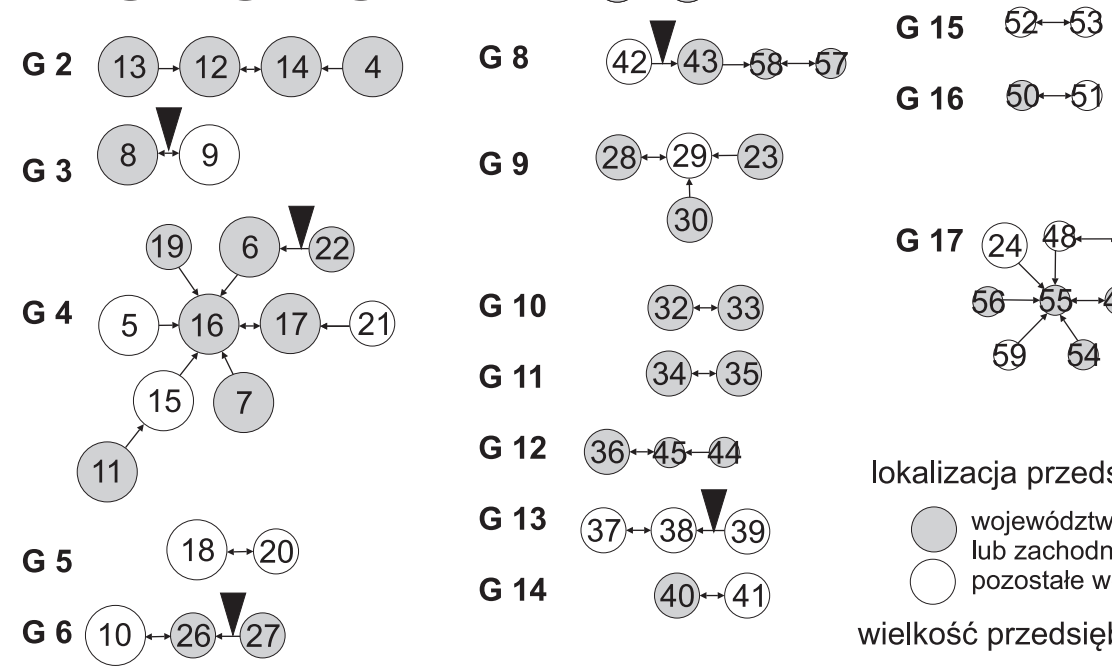

G 9 (28) -23

30.
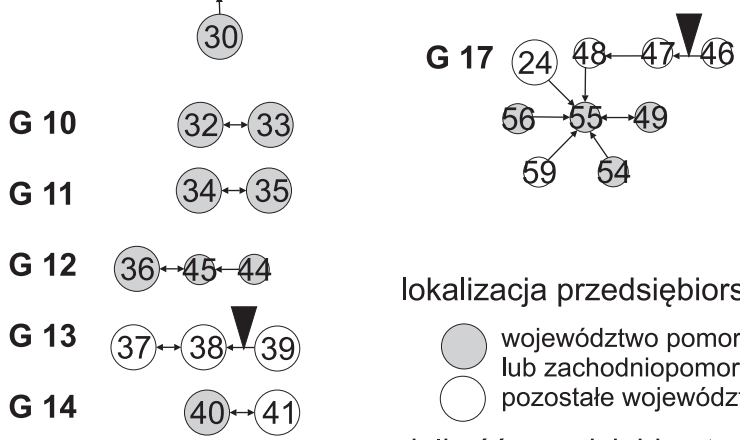

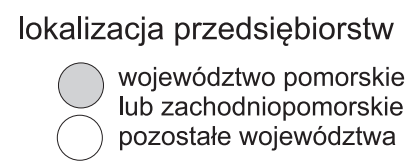

wielkość przedsiębiorstw

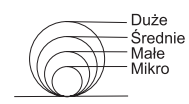

powiązania nieistotne statystycznie

Ryc. 3. Grupy przedsiębiorstw przetwórstwa rybnego według podobieństwa wyboru czynników lokalizacji na postawie analizy elementarnego połączenia Mc Quitty’ego

Źródło: opracowanie własne 
ROZMIESZCZENIE PRZEDSIĘBIORSTW PRZEMYSŁU PRZETWÓRSTWA RYBNEGO

Niezależnie od przyjętego kryterium ${ }^{3}$ należy stwierdzić, że współczesna struktura przestrzenna przemysłu przetwórstwa rybnego cechuje się nierównomiernością rozkładu (ryc. 4).

Zastosowany iloraz lokalizacji wskazuje na nadproporcjonalność rozmieszczenia zakładów przetwórstwa rybnego w strefie nadmorskiej, jednak nadproporcjonalnością, chociaż w znacznie mniejszym stopniu, odznacza się również województwo śląskie.

A
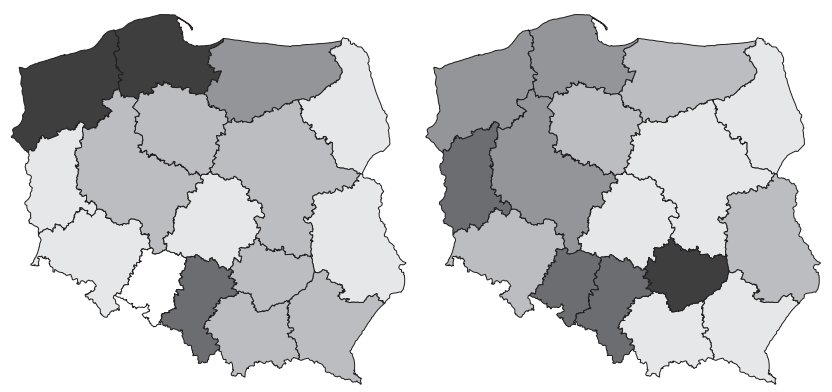

Iloraz lokalizacji LQ

(liczba przedsiębiorstw/powierzchnia bez lasów)

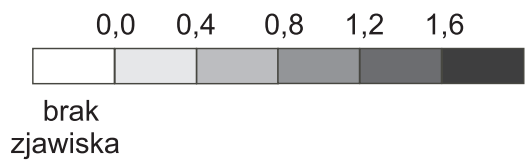

A - iloraz lokalizacji LQ dla zakładów przetwórczych uprawnionych do sprzedaży bezpośredniej na rynek krajowy i rynek UE

B - iloraz lokalizacji LQ dla zakładów przetwórczych uprawnionych do sprzedaży bezpośredniej na rynek krajowy

Ryc. 4. Rozmieszczenie przemysłu przetwórstwa rybnego w Polsce w $2010 \mathrm{r}$. według uprawnień handlowych

Źródło: opracowanie własne na podstawie danych Głównego Inspektoratu Weterynarii

Przedstawiony obraz przestrzenny potwierdza zmiany wag poszczególnych czynników lokalizacji. Mają one jednak uwarunkowania regionalne, które wyraźnie dzielą województwa na dwie grupy. Pierwszą tworzą województwa: pomorskie, zachodniopomorskie oraz warmińsko-mazurskie, w których przetwórstwo rybne oparte jest na tradycyjnych korzyściach lokalizacyjnych wynikających z położenia oraz tradycji i kultury wytwórczości. Druga grupa to nowe regiony koncentracji przetwórstwa (szczególnie województwo śląskie, w znacznej

${ }^{3}$ Przedsiębiorstwa posiadające uprawnienia do sprzedaży na rynek krajowy i rynek UE lub przedsiębiorstwa posiadające uprawnienia do sprzedaży tylko na rynek krajowy - w praktyce obsługujące rynek lokalny, w rzadkich przypadkach rynek regionalny). 
mierze także południowa Wielkopolska, a w dalszej kolejności kujawsko-pomorskie i świętokrzyskie. Dla przedsiębiorstw z tych województw decydujące są nowe czynniki lokalizacji zdefiniowane powyżej, tzn. zasoby pracy w ujęciu kosztowym, kulturowym i kompetencyjnym, chłonność i zamożność rynku oraz dostępność przestrzenna i jej konsekwencje surowcowe, rynkowe i kooperacyjne (Czapliński 2012).

Rozmieszczenie terytorialne zakładów przetwórczych uprawnionych do sprzedaży bezpośredniej tylko na rynek krajowy ma nieco inny rozkład przestrzenny. W województwach nadmorskich funkcjonuje niespełna $15 \%$ tego typu jednostek produkcyjnych, natomiast największa ich nadproporcjonalność występuje w województwach śląskim, lubuskim, opolskim oraz wielkopolskim, których łączny udział w ogóle zakładów wyniósł 56,9\%. Bazą rozwoju tego typu przedsiębiorstw są korzystne warunki naturalne. Niemniej tworzenie akwakultur słodkowodnych jest w dużej mierze determinowane lokalną przedsiębiorczością. W przypadku województwa lubuskiego, opolskiego oraz częściowo śląskiego koncentracja zakładów wynika z kosztów pracy, korzystnego położenia komunikacyjnego oraz z dostępności, zamożności i wielkości m.in. śląskiego rynku zbytu.

Ponadto za ważny należy przyjąć fakt znacznego rozwoju przedsiębiorstw całej grupy na skutek uruchomienia drugiej osi priorytetowej obecnego programu operacyjnego, która dotyczy akwakultury i rybactwa śródlądowego. Dzięki temu na koniec pierwszego kwartału 2012 r. w skali kraju funkcjonowało 446 jednostek produkcyjnych tego typu, wobec około $50 \mathrm{w}$ roku 2005.

Na skutek rosnącego znaczenia nowych czynników lokalizacji następuje spadek udziału przedsiębiorstw przetwórstwa rybnego regionów nadmorskich w polskim przetwórstwie rybnym. Odbywa się to głównie na rzecz silnych ekonomicznie oraz znacznie uprzemysłowionych województw: śląskiego i wielkopolskiego (tab. 2).

Potwierdza to tezę Rachwała (2010: 121) o zmianach struktury przestrzennej przemysłu w Polsce. Pisze on bowiem, iż: ,proces dekoncentracji przemysłu [...] następuje nie w kierunku województw peryferyjnych, o mniejszym znaczeniu przemysłu w gospodarce, ale do województw o tradycyjnie silnym potencjale przemysłowym [...]”.

Tab. 2. Udział przedsiębiorstw przemysłu przetwórstwa rybnego* rozmieszczonych w województwie pomorskim i zachodniopomorskim w ogóle przedsiębiorstw przetwórczych w kraju

\begin{tabular}{|c|c|c|c|c|c|c|c|}
\hline Lata & 2006 & 2007 & 2008 & 2009 & 2010 & 2011 & 2012 \\
\hline $\begin{array}{l}\text { Udział przedsiębiorstw przetwórstwa rybnego } \\
\text { regionów nadmorskich w polskim przetwór- } \\
\text { stwie rybnym (w \%) }\end{array}$ & 62,0 & 59,3 & 58,2 & 58,5 & 57,6 & 54,5 & 54,5 \\
\hline
\end{tabular}

*dotyczy przedsiębiorstw uprawnionych do sprzedaży na rynek krajowy i rynek UE

Źródło: opracowanie własne na podstawie Analiz Rynkowych - Rynek Ryb, nr 1-17, IERiGŻ, Warszawa 
KONCENTRACJA PRZEDSIĘBIORSTW PRZEMYSŁU PRZETWÓRSTWA RYBNEGO

Struktura przestrzenna przedsiębiorstw przetwórstwa rybnego w Polsce skłania także do refleksji nad formami koncentracji przestrzennej jednostek. Wydaje się, że przedsiębiorstwa przetwórcze tworzą wyraźne skupienia o różnej liczebności i powierzchni (ryc. 5).

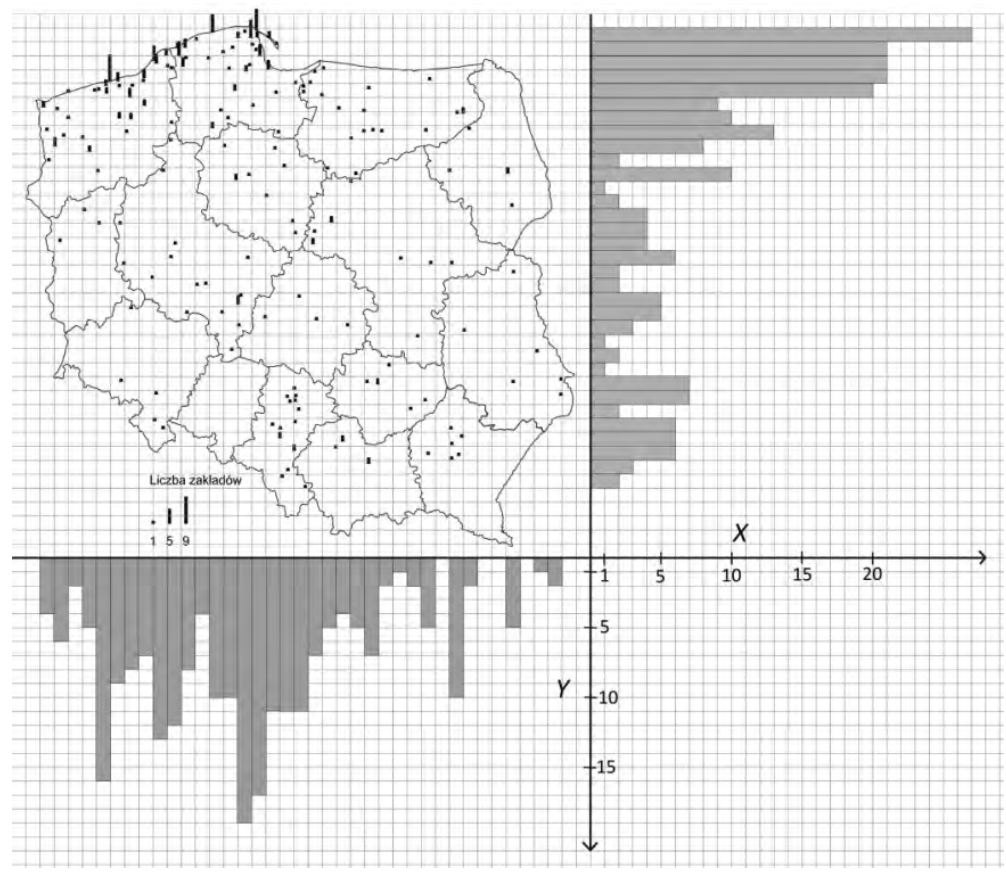

Ryc. 5. Histogram rozkładów brzegowych lokalizacji oraz centroid rozmieszczenia przedsiębiorstw przetwórstwa rybnego w Polsce w 2003 i 2011 r.

Źródło: opracowanie własne na podstawie danych Głównego Inspektoratu Weterynarii - wykaz zakładów zatwierdzonych zgodnie z rozporządzeniem (WE) nr 853/2004 - aktualizacja IV. 2012

Największe z nich pod względem obszaru występują w województwach nadmorskich. Warto jednak zwrócić uwagę, że jednostki produkcyjne przetwórstwa rybnego wykazują także zdolność do koncentracji w innych regionach. Na szczególną uwagę zasługują skupienia: w województwie śląskim (skupienie śląsko-częstochowskie), na granicy województw mazowieckiego i kujawsko-pomorskiego (skupienie płocko-włocławskie), w województwie warmińsko-mazurskim (skupienie warmińskie i skupienie olsztyńskie), a także w województwie podkarpackim (skupienie rzeszowskie) i wielkopolskim (skupienie kaliskie). Rozmieszczenie skupisk przedsiębiorstw, choć nie musi świadczyć o występowaniu między nimi silnych powiązań, może być punktem wyjścia do rozważań nad funkcjonowaniem klastra (klastrów) przetwórstwa rybnego w Polsce.

W teorii klastra nie bez znaczenia pozostaje bowiem geograficzne sąsiedztwo (Ketels 2004; Porter 2001). 
Bliskość jednostek nie jest warunkiem wystarczającym w identyfikacji klastra, niemniej jest istotną przesłanką do jego występowania. Należy zgodzić się z tezą Brodzickiego, Ciołek i Tarkowskiego (2012: 62), że ,prawdopodobieństwo wystąpienia interakcji między niezależnymi podmiotami rośnie wraz ze wzrostem liczby podmiotów, ale i spadkiem odległości pomiędzy nimi”.

Wydaje się więc, że część z wyznaczonych skupisk po przekroczeniu masy krytycznej (liczba przedsiębiorstw oraz liczba i rodzaj powiązań) może tworzyć lokalne klastry przemysłowe. Istotne jest to, czy wśród przedsiębiorców branży rybnej istnieje świadomość korzyści płynących z inicjatyw klastrowych. W tym kontekście można wyróżnić tzw. klastry nieuświadomione (np. słupski klaster przetwórstwa rybnego) lub klastry potencjalne (np. śląski). Natomiast przykładem lokalnego klastra uświadomionego jest klaster rybny w Szczecinie (Ćwiałkowska i in. 2011).

Stąd wydaje się, że proces tworzenia klastra (klastrów) przetwórstwa rybnego w Polsce jest w fazie początkowej związanej m.in. z analizą rynku i wstępnym mapowaniem.

Z definicji Portera (2001: 248) wynika, że „geograficzny zasięg klastra może obejmować jedno miasto lub stan, cały kraj, a nawet grupę sąsiednich krajów”.

W tym miejscu rozważań warto więc postawić pytanie: czy przemysł przetwórstwa rybnego w Polsce można traktować jako klaster krajowy?

W świetle pracy Ketelsa (2004) istnieją ku temu następujące przesłanki:

1) wspólna geograficznie baza surowcowa (np. Norwegia),

2) stosowanie podobnych technologii przerobu, konserwowania, pakowania i transportu (w konsekwencji homogeniczność produktu),

3) podobne powiązania organizacyjne w zakresie zbytu wyrobów gotowych (sieci dystrybucyjne, np. FH Jago S.A. i sieci handlowe, np. Groupe Auchan),

4) proces konsolidacji $\mathrm{i} / \mathrm{lub}$ fragmentaryzacji produkcyjnej w ramach grup kapitałowych (np. Grupa Kapitałowa Graal S.A.),

5) wspólne otoczenie przetwórstwa rybnego B+R (np. Konsorcjum Naukowe Polmar),

6) silna orientacja eksportowa (ok. 90\% wartości obrotów).

Powyższe fakty, a także postępujący proces kompresji czasu i przestrzeni wynikający $\mathrm{z}$ osiągnięć społeczeństwa informacyjnego dają asumpt do dyskusji nad funkcjonowaniem przemysłu przetwórstwa rybnego w Polsce jako niemetropolitalnego, rozproszonego klastra przemysłowego niskich technologii.

\section{WNIOSKI}

Przedstawione fakty, które dotyczą identyfikacji kluczowych czynników lokalizacji oraz konsekwencji przestrzennych decyzji lokalizacyjnych skłaniają do następujących wniosków:

1. Obecnie, najistotniejszymi czynnikami lokalizacji w przetwórstwie rybnym w Polsce są czynniki związane w zasobami pracy, tj. czynnik kosztowy, kompetencyjny, kulturowy. Drugą pod względem ważności grupę stanowią czynniki rynkowe o charakterze jakościowym (np. zamożność rynku) oraz czynniki dostępności przestrzennej podkreślające rolę 
powiązań kooperacyjnych. Znaczenie poszczególnych czynników jest zróżnicowane pod względem wielkości przedsiębiorstw i ich położenia, niemniej są one głównymi stymulantami powolnego procesu dekoncentracji przemysłu przetwórstwa rybnego w Polsce.

2. Proces dekoncentracji dotyczy głównie spadku wielkości potencjału przetwórstwa rybnego w województwach nadmorskich (pomorskie i zachodniopomorskie). Należy jednak podkreślić, że tempo procesu jest powolne i w perspektywie krótkoterminowej nie spowoduje istotnych zmian statystycznych w dotychczasowej strukturze przestrzennej badanej grupy przemysłowej. Warto jednak zwrócić uwagę na nowe lokalizacje przedsiębiorstw w regionach dotąd nie kojarzonych z przetwórstwem rybnym, które są dowodem nie tylko na wypełnianie lokalnej czy regionalnej niszy rynkowej, ale także na rosnące znaczenie nowych czynników lokalizacyjnych, w tym powiązań kooperacyjnych.

3. Nowe lokalizacje przedsiębiorstw, a także zmiany organizacyjno-przestrzenne (m.in. relokacja) jednostek już istniejących spowodowały powstanie „nowych” lub przeformułowanie ,starych” koncentracji przedsiębiorstw przetwórczych. Nowa formuła działania miałaby się opierać na teorii klastra. Jednak proces ich tworzenia w skali kraju jest raczej na etapie inkubacji, a idea klastra krajowego raczej teoretyczna.

Dwa ostatnie wnioski potwierdzają tezę Zioło (2008: 21), iż „w kształtowaniu struktury przestrzennej podstawową rolę odgrywają procesy koncentracji (nawiązujące do ogólniejszych procesów polaryzacji) oraz procesy decentralizacji (dążące do wyrównywania dysproporcji w zakresie uprzemysłowienia i rozpraszania działalności produkcyjnej)".

Formowanie się nowej struktury przestrzennej przemysłu przetwórstwa rybnego w Polsce opiera się na obu tych procesach. Należy jednak podkreślić rosnącą rolę powiązań i budowania formalnych i nieformalnych struktur sieciowych kosztem ujęcia ilościowego.

\section{Literatura / References}

Brodzicki, T., Ciołek, D., Tarkowski M. (2012). Mapowanie klastrów w Polsce-próba dostosowania metody. W: T. Brodzicki, J. Kuczewska (red.), Klastry i polityka klastrowa w Polsce. Konkurencyjność przedsiębiorstw, sektorów i regionów. Gdańsk: Wydawnictwo Naukowe UG, 60-98.

Czapliński, P. (1999). Gospodarka rybna w województwie słupskim na tle polskiego rybołówstwa bałtyckiego. Słupskie Prace Matematyczno-Przyrodnicze, 12c, 17-32.

Czapliński, P. (2012). Consolidation strategy in the polish fishing industry in the light of globalization processes and the European integration. W: P. Slaveykov (red.), Security in the age of global changes. Sofia: University St. Kliment Ohridski, 236-240.

Ćwikałowska, A., Pieńkowski, M., Przybyłowski, M., Rybacka, M., Szultka, S., Tamowicz, P., Walkiewicz, D. (2011). Istniejace klastry i inicjatywy klastrowe w województwie zachodniopomorskim. Szczecin-Gdańsk: Instytut Badań nad Gospodarką Rynkową, ICG.

Dziemianowicz, W. (2008). Konkurencyjność gmin w kontekście relacji władze lokalne - inwestorzy zagraniczni. Warszawa: Wydawnictwo Naukowe Uniwersytetu Warszawskiego.

Godlewska, H. (2001). Lokalizacja działalności gospodarczej. Wybrane zagadnienia. Warszawa: Wydawnictwo WSHiFM.

Ketels, Ch. (2004). European Cluster. Structural Change in Europe 3 - Innovative City and Business Regions. Bollschweil: Hagbarth Publications. 
Kuciński, K. (2009). Geografia ekonomiczna. Warszawa: Wolters Kluwer.

McCann, P., Sheppard, S. (2003). The rise, fall and rise again of industrial location theory. Regional Studies, 37, 6-7.

Porter, M.E. (2001). Porter o konkurencji. Warszawa: Państwowe Wydawnictwo Ekonomiczne.

Rachwał, T. (2010). Struktura przestrzenna i działowa przemysłu Polski na tle Unii Europejskiej w dwudziestolecie rozpoczęcia procesów transformacji systemowej. Prace Komisji Geografii Przemystu Polskiego Towarzystwa Geograficznego, 16, 105-124.

Stryjakiewicz, T. (2010). Przemiany w geografii przemysłu. Prace Komisji Geografii Przemysłu Polskiego Towarzystwa Geograficznego, 15, 30-44.

Wieloński, A. (2005). Geografia przemystu. Warszawa: Wydawnictwo Naukowe Uniwersytetu Warszawskiego.

Zioło, Z. (2008). Problemy badawcze struktury przestrzennej przemysłu. Prace Komisji Geografii Przemystu Polskiego Towarzystwa Geograficznego, 11, 9-25.

Paweł Czapliński, dr, Akademia Pomorska w Słupsku, Instytut Geografii i Studiów Regionalnych Absolwent geografii Akademii Pomorskiej w Słupsku oraz zarządzania i ekonomii Politechniki Gdańskiej. Doktor nauk o Ziemi - Uniwersytet Pedagogiczny w Krakowie (2004). W latach 1996-2004 asystent, a następnie adiunkt Instytutu Geografii i Studiów Regionalnych AP w Słupsku. Sekretarz komitetu redakcyjnego Słupskich Prac Geograficznych oraz członek rad redakcyjnych czasopism: Prace Komisji Geografii Przemysłu Polskiego Towarzystwa Geograficznego oraz PrzedsiębiorczośćEdukacja. Autor ponad siedemdziesięciu publikacji i monografii z zakresu transformacji struktur przestrzennych przemysłu Polski Północnej, funkcjonowania i perspektyw rozwoju przemysłu przetwórstwa rybnego w Polsce, przedsiębiorczości młodzieży i osób starszych na obszarach wiejskich oraz wybranych aspektów z zarządzania i administracji samorządowej.

Pawel Czapliński, Ph.D., Graduate of Geography at the Pomeranian Academy in Slupsk, and Management and Economy at Gdańsk University of Technology. Doctor of Geographical Sciences Pedagogical University in Cracow (2004). In 1996-2004 Assistant Lecturer and then Senior Lecturer in the Institute of Geography and Regional Studies at Pomeranian Academy in Slupsk. Secretary of the Editorial Committee of Slupsk Geographical Works and Member of the editorial board of journals: Prace Komisji Geografii Przemysłu Polskiego Towarzystwa Geograficznego and Przedsiębiorczość Edukacja. Author of more than seventy publications and monographs with subjects of transformation of spatial structures of industry in Northern Poland, performance and prospects of the development of the fish processing industry in Poland, entrepreneurship of young people and the elderly in rural areas and some aspects of the management and administration of local government.

adres/address: Akademia Pomorska w Słupsku

Instytut Geografii i Studiów Regionalnych

ul. Partyzantów 27, 76-200 Słupsk, Polska

e-mail:somma@o2.pl 